\title{
Н.И. Данилина
}

\section{ДИНАМИКА ФУНКЦИОНИРОВАНИЯ ДЕРИВАЦИОННО- АССОЦИАТИВНОГО МЕХАНИЗМА В ПРОЦЕССЕ ВОСПРИЯТИЯ ТЕКСТА (ЭКСПЕРИМЕНТАЛЬНОЕ ИССЛЕДОВАНИЕ)}

\author{
В статье описан ассочиативный эксперимент с предъявлением стимулов в лексико- \\ деривационных контекстах, вписанных в связный текст, с иелью моделирования вос- \\ приятия речи в ситуации неполного понимания. Выявлено, что деривационный анализ \\ способен выполнять разные функции: когнитивную, фразопорождающую, объясни- \\ тельную; использование их определено возрастом и специальностью испытуемых. \\ Применение деривационного ассоциирования ограничено свойствами стимула, кон- \\ текста и текстопорождающей интенцией. \\ Ключевые слова: ассоциативный эксперимент, текст, деривация.
}

Деривационно-ассоциативный эксперимент (ДАЭ) давно и прочно вошел в исследовательскую практику. Разные его виды получили обоснование и были многократно опробованы в работах Н.Д. Голева и его учеников [1-4]. Ценность методики ДАЭ для изучения системных отношений в лексике не вызывают сомнений. Другой аспект механизма деривации, активно исследуемый представителями упомянутого научного направления, - её роль в текстопорождении. В работах текстологической ориентации также используются экспериментальные методики, одна из которых - традиционный для психолингвистики клоуз-тест. В диссертации [2] методики ДАЭ и клоуз-теста оказались совмещены: испытуемым предъявлялся текст, сконструированный из лексико-деривационных контекстов. Эксперимент проводился с дошкольниками, поэтому текст (вместо отдельных контекстов) был вынужденной формой подачи стимулов. Однако мы полагаем, что полнотекстовая методика может составить самостоятельную разновидность ДАЭ. Она способна моделировать одновременно процесс и восприятия речи, отражением которого является ассоциативный механизм, и порождения, задаваемого прагматической установкой на получение адекватного текста. При этом сформированность речевых навыков и умений, уровень самоконтроля в процессе речепорождения, возможность и способность информантов осознанно выполнить «соавторскую» роль может составить один из параметров оценки экспериментального материала. Место механизма деривационного анализа в иерархии прогностических детерминант текста до сих пор изучалось только в аспекте переводческой деятельности, т.е. на материале речи взрослых носителей языка с соответствующим уровнем и характером образования [5]. Влияние социолингвистического (возрастного, образовательного и т.п.) фактора в ДАЭ также специально не рассматривалось. Представляет интерес и предъявление в качестве стимулов искусственных слов, ибо таким образом моделируется нередкая в опыте многих реципиентов ситуация неполного пони- 
мания, возникающая, в частности, из-за разницы индивидуальных лексиконов субъектов общения. В данной статье мы ставим перед собой задачу повторить эксперимент Е.А. Аввакумовой с испытуемыми разного возраста и образования и при интерпретации результатов учесть взаимодействие различных факторов, влияющих на тип реакции.

Состав испытуемых: учащиеся 2А и 6А классов СОШ № 94 г. Саратова по 25 чел.; студенты 1-го курса Саратовского медицинского университета (СГМУ) 29 чел., для которых русский язык является родным, и 23 чел., владеющих русским языком с 3-10 лет и обучавшихся в русских школах; студенты 1-2-го курса Саратовского университета (СГУ) 12 студентов направления «Английская филология», 10 - «Отечественная филология», 8 - «Мировая художественная культура»); филологи-преподаватели СГУ и СГМУ старше 30 лет - 21 чел. Выбор испытуемых определялся следующими соображениями. Начальная школа - вывод практического навыка морфемного и деривационного анализа на сознательный уровень, средняя школа - период наиболее активного изучения структуры слова в школьной программе, к семнадцати годам в целом заканчивается формирование языковой личности [6. C. 230]. В данный период, по нашему мнению, уже можно проследить различия между гуманитариями, для которых внимание к слову и тексту приоритетно, и представителями других специальностей. Общение с людьми, для которых русский язык не является родным, в некоторых коллективах составляет значительную часть коммуникативного процесса, поэтому при моделировании ситуаций восприятия речи следует учитывать и этих слушателей. Привлечение к участию в эксперименте представителей старшего поколения имеет целью проследить влияние на ассоциации различий в жизненном и профессиональном опыте информантов ${ }^{1}$.

За основу экспериментального материала взят текст из [2. С. 66-67]. В него добавлены стимулы, обладающие дефектной членимостью (сонатина, стеклярус), высокой степенью идиоматичности семантики, относящиеся к пассивному лексикону современного горожанина или вовсе ему незнакомые (бортник, старьёвщик), неузуальный аналог дефектно членимых слов (земличные) и стимул нетамыгранцы, образованный по неузуальной модели. В результате текст принял следующий вид:

В одном сказочном городе жили коротышки. Были они очень забавнье, потому что говорили иногда непонятные слова, но друг друга всегда понимали. Каждый занимался каким-нибудь делом: кто-то дом строил, кто-то деревья сажал, а кто-то на скрипке играл. Вот как-то раз иофер Баранкин работал у себя в гараже. И пришел к нему друг. "Что ты все здесь сидишь? - спрашивает, - Вон летчик в небе уже давно». (1) «Раз он летчик, то пусть он... (2) А я водитель, значит, буду...», - с достоинством ответил Баранкин и стал щелкать выключателем. "Ты зачем выключателем щелкаешь?» - опять спрашивает друг. (3) «Как зачем? Чтобы...». «Ты вчера на своей машине по лесу ездил, а она у тебя гудымит и гудымит». Баранкин нисколько не удивился этому слову, ведь коротьики друг друга всегда пони-

${ }^{1}$ За помощь в проведении эксперимента мы благодарим преподавателей СГУ Н.Г. Мальцеву и Е.А. Разумовскую и учителя СОШ № 94 М.И. Носачёву. 
мали. Поэтому он ответил: «Как же ей не гудыметь? (4) Машины не могут не...». Баранкин сел в машину и поехал по городу. Едет и смотрит, что другие коротылики делают. Вот учитель - он учит. (5) Вот каменщик-он... (6) Вот скрипач - он... Его любимая вещь - (7) сонатина, это ... (8) Вот бортник - он... (9) Вот красари - они ... (10) Вот Зонтарь - он делает... и украшает (11) стеклярусом. Это... А вот стоят коротышки и слушают Загандёра, слушают и смеются. Потому что (12) на то он и Загандёр, чтобы ... (13) А вон старьёвщик навстречу едет на телеге. Его потому так называют, что он... (14) Вдруг появились на дороге нетамыгранцы. Они всегда... Баранкин затормозил. Тут Баранкин увидел своего друга Копалкина. Они поздоровались и привычно пошутили друг над другом. (15) «Тебя зовут Баранкин, потому что ты...». (16) «Тебя зовут Копалкин, потому что тыл...». Копалкин сказал: (17) «Посмотри, каких шишенят я нашел. Я их потому так назвал, что это...» Баранкин посмотрел и порадовался за Копалкина: «Какие земличные шишенята!» (18) «Это они потому земличные, что...». Сели друзья в машину и они поехали всем рассказывать о иииенятах.

Данный текст зачитывался испытуемым, и предлагалось письменно заполнить лакуны. Число полученных реакций в нашем материале больше числа испытуемых, так как в некоторых случаях на один стимул одним информантом давалось несколько реакций, разделенных знаком /, каковые мы считали разными; реакции, записанные с использованием пояснений (играют (мешают)), мы рассматривали как единые.

В работах, посвященных проблеме ДАЭ, можно найти разные классификации реакций: от более или менее обобщенной [7. С. 25] до весьма дробной [3. С. 62-63]. Поскольку в задачи нашей статьи входит не классификация ответов, а изучение структуры ассоциативного поля и факторов, влияющих на её формирование, описание встретившихся в материале реакций будет предварять основное изложение и носить обобщенный характер.

Среди формально-семантических ассоциаций (ФСА) преобладает реагирование непосредственным производящим (или трактуемым как таковое). Например, летчик - летает; бортник - моет борт у корабля; старьёвщик старьё собирает. Гораздо реже встречается реагирование другими членами словообразовательного гнезда. Например, выключатель - переключить; Копалкин - копуша, землекоп; старьёвщик - старинный. Примеры перспективной деривации немногочисленны: бортник - бортничествовать; красари красарить, красарировать; загандёр - загандёрничать, загондёривать, загондёрывать. Искусственные слова, реализующие деривационные потенции стимулов, появляются в нашем материале у испытуемых разных групп, но лишь для некоторых лексем и будут описаны в соответствующих местах. К ФСА мы относим и «ослышки» - формальные реакции на фонетически неправильно распознанный или расчлененный стимул. Таких примеров тоже немного: бортник - убирает, собирает, бурит; старьёвщик - всегда стоит, делает сталь; нетамыгранщы - делают томографию на гранище (вероятно, стимул распознан как нетомогранщы, т.е. «не имеющие результатов томографии»); красари - крыс ловят ...; сонатина - сонеты для сна, нотная тетрадь («с нотами»). Последние примеры позволяют предположить установку 
на языковую игру. Представлены в нашем материале и ФСА на суффиксальную часть стимула. Подобные реакции единично встретились для стимула красари (слесари, косари) и довольно многочисленны для стимула шишеня$m a$. К периферии ФСА можно отнести ассоциаты, содержащие синонимы или перифразы предполагаемого производящего, в том числе и неверно отражающие реальную мотивировку, ср. имплицитные реакции в классификации [3. С. 62]. Например, водитель - шоферить; красари - рисуют на заборе (ср. красят забор); Копалкин - роешь ямы. В целом ответы подобного типа в нашем материале нечасты.

Следующая степень отдаления реакций от ФСА представлена такими ассоциатами, которые имеют со стимулом устойчивые для данного языкового коллектива когнитивные связи, фиксируемые толковыми, ассоциативными и другими словарями, и актуализируют семы стимула, не отраженные в его внутренней форме. В случае с неузуальными стимулами ассоциированию подвергается предполагаемое производящее. Например, водитель - ездить; стеклярус - бисер; бортник - добывает мёд; сонатина - музыкальное произведение; Копалкин - лопата, садовник, археолог. Реакции подобного типа составляют в нашем материале значительный пласт для всех узуальных стимулов, а также для некоторых неузуальных. Такие реакции принято называть семантическими [7. С. 25], однако, чтобы отличить их от тех семантических, которые будут описаны далее, мы будем именовать их здесь системноассоциативными или системно ориентированными (СОА).

Следующая разновидность семантических реакций не фиксируется ассоциативными словарями, так как порождена не просто ДАЭ, а его текстовой формой. Мы имеем в виду заполнение лакун лексикой, семантически вписывающейся в контекст, но не связанной со словом-стимулом, ср. ассоциативные реакции в [3. С. 63]. Назовем такие реакции контекстно ориентированными (КОА). Примеры: Ты зачем выключателем щелкаешь? Чтобы тебя напугать; Раз он летчик, то пусть он и летает в небе. А я водитель, значит, буду не в небе, а на земле работать; А вон старьёвщик навстречу едет на телеге. Его потому так называют, что он едет на телеге, но на них уже никто не ездит. В таких ответах прослеживается реакция либо на те или иные вербальные составляющие контекста, либо на компоненты описываемой ситуации. Так, в примере со стимулом старьёвщик объект «телега» как компонент ситуации порождает ассоциацию «старомодно», данную в виде перифразы. В примере со стимулом выключатель отражена опосредованная реакция на описанное событие: щелчок выключателем - гаснет свет - становится темно - собеседнику страшно. Впрочем, восстановить ход мысли испытуемого не всегда удается. Например, каменщик - копает; нетамыгранuьь - в маленьких ботиночках. Катализатором появления КОА служит невозможность по тем или иным причинам вычленить из стимула мотиватор (загандёр) или слабая синтаксическая позиция стимула в контексте (выключатель), и это делает по крайней мере часть таких ответов синонимами отказов. Однако сам факт появления КОА симптоматичен: он демонстрирует, с одной стороны, роль смыслового контекста и пресуппозиций в процессе восприятия речи, с другой - действие установки на текстопорождение (прагматический «запрет» на отказы). 
В нашем материале встретился еще один тип реакций, неупоминаемый в работах по ДАЭ, - реагирование лексикой максимально обобщенного характера, часто не вписывающейся даже в семантический контекст. Такая лексика может быть отнесена, по сути дела, к любому стимулу, что видно из следующих примеров: летчик, бортник, каменщик - занимается своим делом; Баранкин, бортник - хороший человек; стеклярус - что-то. Такие реакции можно было бы назвать «нулевыми» или «асемантическими» (АСА). Все они синонимичны отказам. Причиной их появления, вероятно, является специфическое проявление фразопорождающей интенции: стремление заполнить синтаксические позиции при неспособности достаточно быстро подыскать «нужные заполнители» в своём индивидуальном лексиконе. «Нулевые» ответы встретились нам преимущественно в анкетах студентов, для которых русский язык неродной.

К периферии ассоциативной области принадлежат фонетические (формальные) реакции (ФА). Доля ФА в общем числе ответов существенна в анкетах медиков с неродным русским для стимулов Копалкин (коптишь, колпак, палка) и нетамыгранцы (мигрируют, иммигранты), в анкетах школьников - только для стимула нетамыграниь (мытые, немые, немиы, иммигран$m b l$ ). Кроме того, фонетическое ассоциирование корня сопутствует большинству реакций на стимул шишенята. Оригинальную разновидность ФА представляют аллитерация и рифма. В нашем материале они встретились в трех анкетах студентов-гуманитариев и одной преподавательской, в основном как сопровождение реакций другого типа: сонатина - подставка для скрипки из сатина, скрипач - струны настраивает, зонтарь - золотые зонты, нетамыгранцы - делают томографию на границе; нетамыграниы таниуют танщы, Баранкин - бубликов едянкин, Копалкин - землю ковырялкин; сонатина - сонеты для сна; сонатина - подлая скотина.

Что касается протяженности реакций, то большинство выходов однословно (особенно у школьников и медиков) либо представляет собой двухсловное словосочетание. Более развернутые реакции, часто совмещающие ассоциаты разных типов, дают студенты-гуманитарии, преимущественно культурологи. Примеры: нетамыгранцы - играют на дороге и мешают ехать; водитель - развозить людей по долам и весям; скрипач - радует людей мелодией своей скрипки; старьёвщик - собирает старые вещи коротышек и дарит им вторую жизнь; стеклярус-маленькие и большие прозрачные бусины; Баранкин - баранку изельми днями крутишь, а по вечерам с ними чай пьёшь; Копалкин - знатно весь огород перекапываешь каждый год. Доля развернутых реакций в ответах студентов-гуманитариев составляет $19,1 \%$, тогда как в ответах других испытуемых - от $0 \%$ у второклассников до $10,4 \%$ у преподавателей. Можно предположить, что целью развернутого реагирования является создание качественного текста, в основе его лежит осознанное принятие испытуемыми соавторской роли. Об этом свидетельствует и наблюдаемая согласованность реакций в рамках одной анкеты. Например, к $a$ менщик - строит новый домик, бортник - отесывает дерево, красари - огораживают новые домики каменщика; шишенята - мышата, земличные живут в норках. В анкетах медиков, напротив, встречаются случаи противоречия соседних реакций как друг другу, так и, иногда, контексту. Например, 
Баранкин - баран, Копалкин - отказ; Зонтарь - зонты, стеклярус - стекольщиик.

Отдельно следует упомянуть о встретившемся в некоторых анкетах метаассоциативном компоненте. Это пометы :) и !, использованные в двух анкетах студентов-гуманитариев и один раз в анкете медика. Филолог маркирует искусственные слова и ассоциаты, которые не являются реальными производящими для стимула (Баранкин - водитель:)), сопровождая их альтернативами: каменит:) Кладет кирпичи; скрипит:) Играет на скрипке; зонтари:) Зонты; бортует:) За пчелами ухаживает. В анкете культуролога маркируются реакции, подчеркивающие нереальность, шуточность ситуации, в том числе и искусственные слова, но альтернатив не предлагается: выключатель - устроить светомузыку!; загондёр - гундерить!; зонтарь - клубничные зонтики!; старьёвщик - известный антиквариамус!; Баранкин - курзяблик!; Копалкин - ральбанбо!; земличные - землянику любят! В этой же анкете: летчик - готовит пирог и купит конфет; водитель - есть баранки и свистеть в рогалик. В анкетах преподавателей метаассоциативный компонент обычно представлен образованием искусственных глаголов в тех случаях, где мотиватор легко вычленим (старьевать любит, баранишь, красарят, нетамыграют по вечерам). Так, в одной анкете встретилось 8 неузуальных или не соответствующих ситуации глаголов, некоторые с обозначенным ударением: лётает, каменеет, скрипает, бортает, красАют, загундивать, старится, доигрываются (из этой же анкеты: сонатина - подлая скотина). В другой анкете метаассоциативный компонент представлен комментариями, намеренно разрушающими прагматическую целостность текста: ... гудыметь. Это их прямое занятие; смеяться абсурдности его профессии; очень старый и к тому же любит винтаж; попал на букву $K$; у меня лингвокреативная деятельность такая; надобно же их как-нибудь определить (из этой же анкеты: ма-а-а-аленькая соната). Отдельно упомянем две отсылки к прецедентным текстам: бортник - бортанул бокра, шишенята - шит бул. Метатекстовый компонент можно рассматривать как своеобразную «диалогизацию» ситуации общения: испытуемый не только воспринимает и продуцирует экспериментальный текст, но и хочет сообщить экспериментатору, что делает это осознанно, выбирая форму выражения, что ему нравится рефлексия над речью.

Обратимся к анализу соотношения разных типов реакций на тот или иной стимул в разных группах испытуемых и попытаемся выявить факторы, обусловливающие появление реакций того или иного вида. Предъявленные стимулы разделим на 6 групп: 1) узуальные свободно членимые, входящие в активный лексикон всех испытуемых (летчик, водитель, выключатель, скри$n a 4)$; 2) узуальные свободно членимые, принадлежащие пассивному лексикону большинства испытуемых (каменщик, старьевщик, бортник); 3) узуальные дефектно членимые, также принадлежащие к пассивному словарному запасу (стеклярус, сонатина); 4) неузуальные свободно членимые (зонтарь, красари, Баранкин, Копалкин); 5) неузуальные с уникальными морфами (иишенята, земличные, загандёр); 6) неузуальные сложения (гудыметь, нетамысгранцы). 
В первой группе наибольший процент ФСА у всех испытуемых дает стимул лётчик, тогда как стимулы скрипач и водитель демонстрируют «оттяжку» реакций в сторону СОА, а выключатель - КОА (см. табл. 1, 2). Здесь и далее числа в таблицах - это процент реакций того или иного типа.

\begin{tabular}{|c|c|c|c|c|c|c|c|c|c|c|c|c|}
\hline \multirow[b]{4}{*}{ Группа } & & & & & & & & & & & & өлица \\
\hline & \multicolumn{12}{|c|}{ Стимул } \\
\hline & \multicolumn{6}{|c|}{ лётчик } & \multicolumn{6}{|c|}{ скрипач } \\
\hline & ш2 & ш6 & $\begin{array}{c}\text { СГМУ- } \\
\text { н }\end{array}$ & $\begin{array}{c}\text { СГМУ- } \\
\mathrm{p}\end{array}$ & СГУ & $\begin{array}{c}\text { Взрос- } \\
\text { лые }\end{array}$ & ш2 & ш6 & $\begin{array}{c}\text { СГМУ- } \\
\mathrm{H}\end{array}$ & $\begin{array}{c}\text { СГМУ- } \\
\text { p }\end{array}$ & СГУ & $\begin{array}{c}\text { Взрос- } \\
\text { лые }\end{array}$ \\
\hline $\begin{array}{l}\text { ФСА } \\
\text { экспл. }\end{array}$ & 80 & 84 & 91,3 & 96,6 & 83,3 & 90,5 & 48 & 60 & 56,5 & 66,7 & 61,3 & 72,7 \\
\hline $\begin{array}{l}\text { ФСА } \\
\text { импл. }\end{array}$ & - & - & - & 3,4 & - & 4,7 & - & - & - & - & - & - \\
\hline $\mathrm{COA}$ & 4 & 8 & - & - & 10 & - & 44 & 40 & 39,1 & 33,3 & 29 & 27,3 \\
\hline KOA & 8 & 4 & - & - & 3,3 & - & 4 & - & 4,3 & - & 6,5 & - \\
\hline ACA & - & 4 & 4,3 & - & 3,3 & 4,7 & - & - & - & - & 3,2 & - \\
\hline отказы & 4 & - & - & - & - & - & 4 & - & - & - & - & - \\
\hline
\end{tabular}

\begin{tabular}{|c|c|c|c|c|c|c|c|c|c|c|c|c|}
\hline \multirow[b]{4}{*}{ Группа } & & & & & & & & & & & & аблица 2 \\
\hline & \multicolumn{12}{|c|}{ Стимул } \\
\hline & \multicolumn{6}{|c|}{ водитель } & \multicolumn{6}{|c|}{ выключатель } \\
\hline & ш2 & ш6 & $\begin{array}{c}\text { СГМУ- } \\
\text { н }\end{array}$ & $\begin{array}{c}\text { СГМУ- } \\
\text { p }\end{array}$ & СГУ & $\begin{array}{c}\text { Взрос- } \\
\text { лые }\end{array}$ & ш2 & ш6 & $\begin{array}{c}\text { СГМУ- } \\
\text { н }\end{array}$ & $\begin{array}{c}\text { СГМУ- } \\
\text { p }\end{array}$ & СГУ & $\begin{array}{c}\text { Взрос- } \\
\text { лые }\end{array}$ \\
\hline ФСА экспл. & 20 & 68 & 78,3 & 56,7 & 43,3 & 52,2 & 20 & 32 & 31,8 & 51,7 & 40 & 50 \\
\hline ФСА импл. & - & - & 4,3 & - & 6,7 & 26,1 & 8 & - & 9 & 10,3 & - & 18,2 \\
\hline $\mathrm{COA}$ & 72 & 24 & 13 & 40 & 36,7 & 17,4 & 40 & 32 & $\begin{array}{llll}- & & & \end{array}$ & 17,2 & 13,3 & 18,2 \\
\hline KOA & 4 & 8 & 4,3 & 3,3 & 13,3 & 4,3 & 12 & 32 & 45,5 & 10,3 & 40 & 13,6 \\
\hline отказы & 4 & - & - & - & - & - & 20 & 4 & 13,6 & 10,3 & 6,7 & - \\
\hline
\end{tabular}

Слово лётчик высокочастотно (436 вхождений в устный подкорпус НКРЯ [8]), имеет высокочастотное производящее (летать 797, лететь 1080), толкуется через однокоренные слова («водитель самолета» [9]), ассоциация его с производящим глаголом зафиксирована в [10]. Альтернативные обозначения типичных действий именуемого лица (как того требует синтаксический контекст в эксперименте) в непрофессиональной речи отсутствуют. Совокупность перечисленных факторов ведет к тому, что реакции деривационного типа составляют для данного стимула подавляющее большинство. Преобладают реакции, содержащие непосредственное производящее: летает / летит (117). Встречаются и реакции с другими членами словообразовательного гнезда: прилетит, полетит (2), взлетит, взлетит до небес. Примеры недеривационных реакций: пилотирует, пилотчик; военный, в небо выходит, разгоняет тучи, птица.

Слово скрипач в словарях толкуется через своё производящее («музыкант, играющий на скрипке» [9]); оба слова не принадлежат к высокочастотным (64 и 123 вхождения в [8]). Ассоциация скрипач - скрипка зафиксирована в [10], но не является для стимула самой сильной. Лексема скрипач не отглагольна, типичное действие именуемого лица обозначается не однокоренным словом, однако опосредованная ассоциация «лицо - действие» зафиксирована в [10] (играть - на скрипке). Таким образом, неотглагольность стимула при контекстуальной необходимости обозначить действие провоцирует смещение реакций в сторону блока СОА, хотя процент деривационных выходов достаточно высок. Показательно, 
что реакция играет чаще встречается у школьников и медиков (по 17), предпочитающих однословное реагирование. Остальные СОА содержат лексему музька: музыку творит, исполняет великолепную по звучанию музыку и т.п. Что касается ФСА, то у всех испытуемых, кроме второклассников, преобладающей является на скрипке играет (61). У второклассников же доминирует мнимое производящее - глагол скрипеть (9), что может свидетельствовать о недостаточной закрепленности в сознании детей ассоциативного поля лексемы скрипач и, как следствие, вариативное толкование её внутренней формы. Глаголы появляются и в ответах взрослых. Но здесь они свидетельствуют, скорее, об установке на языковую игру, что подтверждается наличием не только узуального скрипит (5 у медиков, 6 у гуманитариев), но и искусственных скрипает (2), скрипучит, скрипачит (только у филологов).

У лексемы водитель связь с производящим водить не фиксируется словарями («тот, кто управляет самодвижущейся машиной» [9]), хотя оба слова обладают довольно высокой частотой употребления (243 и 342 вхождения в [8]). Анализ контекстов в НКРЯ показывает, что совместно со словом водитель из глаголов встречаются преимущественно работать (работать водителем) и ехать / ездить (последнее вообще частотнее, чем водить: 2125 вхождений в [8]). Таким образом, есть основания констатировать системно-ассоциативную связь наименования лица водитель с действием ездить, которая и проявилась в экспериментальном контексте, «оттеснив» деривационную связь с водить (особенно сильно - у второклассников): ездить (38), ехать (4), ехать по проспекту, ехать на машине, ездить по дорогам. Другие СОА: возить людей (3), перевозить пассажиров. Среди СОА следует отметить появление у школьников неглагольных ассоциатов, фиксируемых [10] (шофёр, шофёром, в машине, ср. также водитель, водителем), тогда как в старших возрастных группах подобные реакции отсутствуют. В блоке ФСА преобладают реакции, содержащие непосредственное производящее водить / вести (81): водить (68), водить машину (10). Самый высокий процент однословных ответов водить отмечен у студентов с неродным русским. Вероятно, этой категорией испытуемых не ощущается семантическая неполнота переходного глагола, употребленного без названия объекта действия. У преподавателей значительная часть ответов лежит в зоне реакций, имплицитно связанных с производящим: шоферить (2), рулить (3), управлять авто. Таким образом, снижению доли деривационных реакций на стимул водитель способствуют его собственные свойства: транзитивность, требующая двухсловного реагирования, и отсутствие словарной фиксации связей с производящим.

Стимул выключатель, несмотря на лексикографическую закрепленность связи с производящим («приспособление для выключения и включения электрического тока» [9]), даёт самый низкий в рассматриваемой группе процент ФСА, большое количество КОА и отказов. Такое положение обусловлено отсутствием у экспериментального контекста достаточной деривационной силы, см. методику подсчета в [4. С. 43-56]. Играет роль и лексический состав фразы: вопрос зачем в норме относится к действию (в нашем случае щёлкаешь), а не к предмету. Сама экспериментальная фраза не совсем неудачна с точки зрения описываемой ситуации: глагол несовершенного вида щёлкать подразумевает многократное действие, тогда как для включения или 


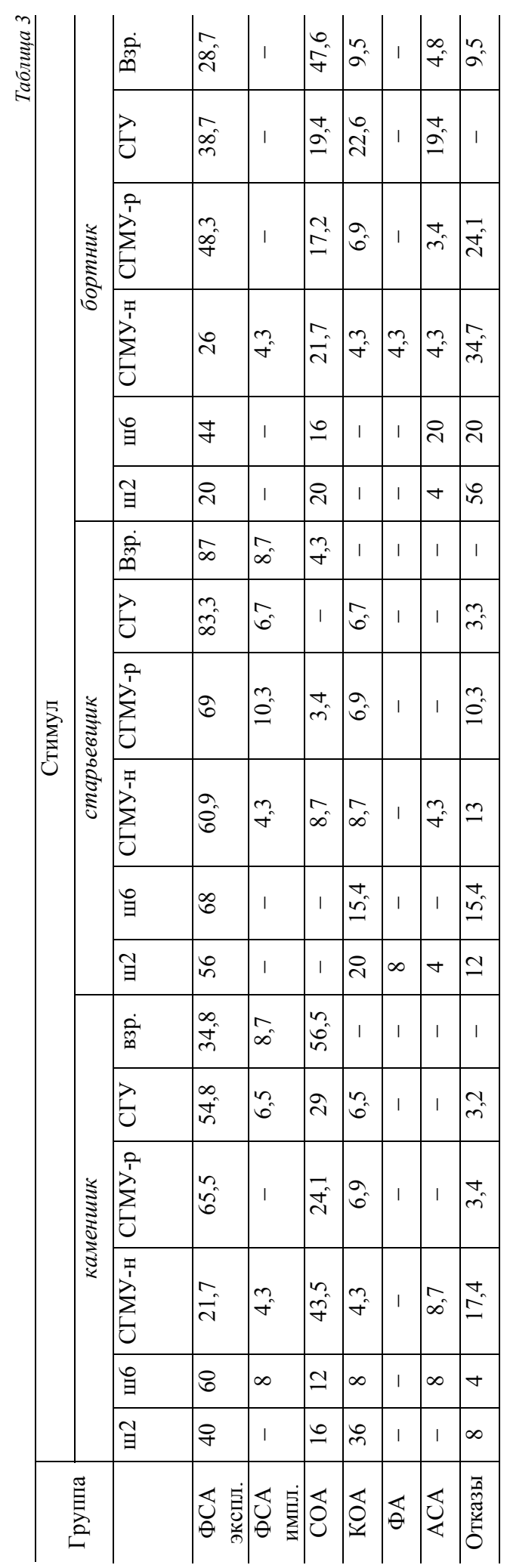


выключения электричества достаточно действия однократного (щеёлкнуть), что вызывает переключение внимания испытуемых на факт многократности и попытки его объяснения, т.е. КОА (проверить работоспособность, устроить светомузыку, вызвать помощь и т.п., а также щеёлкнло, щеёлкать, пощёлкать), а при невозможности подобрать таковое - отказы. Показательно, что студенты с неродным русским не дают даже СОА со словом cвеm, которые широко представлены у всех категорий информантов-носителей русского языка (свет горел, было светло, кончилось электричество, видимость создать). Минимальное количество КОА и отказов дали преподаватели. Они чаще других соотносили стимул не только со словом свет, но и с обозначениями объектов (чтобы машина включилась, включить механизм), используя при этом имплицитные связи (завести мотор, чтобы машина ехала).

Перейдём к анализу реакций на стимулы второй из выделенных групп (табл. 3). Самый высокий процент ФСА порождает старьёвщик, что обусловлено, наряду со свойствами самого стимула, мотивационной ориентацией контекста. «Оттяжка» реакций происходит, главным образом, в область КОА и отказов и свойственна преимущественно школьникам, незнакомым с названным явлением действительности. «Маркированным» компонентом описываемой ситуации оказывается объект «телега» (на телеге, водит трактор c телегой), эта лексема встретилась в 11 из 15 КОА; впрочем, такие ответы можно трактовать и как имплицитно связанные с мнимым производящим старомодно. ФСА на стимул старьёвщик являются у разных информантов следствием двух разных процессов: воспроизведения толкования знакомого слова, у которого связь с мотиватором закреплена лексикографически («торговец старыми, подержанными вещами» [9]), и деривационного анализа незнакомого слова с прозрачной внутренней формой. Работа того или другого механизма легко опознается по выбору испытуемым мотиватора. Так, в ответах взрослых носителей русского языка преобладает слово старьё или словосочетание старые вещи (60,9\% преподаватели, 58,1\% студенты-гуманитарии, 47,9\% медики): старьё собирает и продаёт, скупает старые вещии и т.п.; ответы с имплицитными отношениями: собирает хлам, барахло собирает. Однако и здесь не исключены ошибки: коллекционирует старинные вещи. Студенты, для которых русский язык неродной, и школьники на роль мотиватора выдвигают преимущественно прилагательное старый (36\% 2 кл., 42,3\% 6 кл., 39,1\% студенты). Среди ФСА второклассников встретилось довольно много «ослышек»: стоит (4), делает сталь, ср. ФА станёвщчик, станёшь, что свидетельствует о трудностях фонологического распознавания незнакомого слова. Часть ФСА филологов реализует установку на языковую игру - трактовку экспериментального задания как необходимость дать глагольный ответ: старьит, старьевать любит, старится.

В поле реакций на стимул каменщик так же, как в полях стимулов водитель и скрипач, обнаруживаются два «фокуса»: ФСА и СОА. Причина появления второго и в этом случае определяется свойствами стимула: неотглагольность имени деятеля при необходимости назвать характерное действие. Глаголом, имеющим опосредованную ассоциативную связь со словом каменщикк, является строить (ср. строитель - каменщцик (3) [10]). Он и представлен в большинстве COA (29). Принадлежность стимула к пассивному 
лексикону испытуемых и их неуверенность в знании значения данного слова ведут к деривационному реагированию путем объяснения производного через отношение к производящему, однако идиоматичность внутренней формы часто препятствует правильности трактовки субъектно-объектных отношений. Так, наряду с лексикографически верными ответами камни кладет, кладет кирпичи, стену возводит (ср. «рабочий, производящий кладку различных сооружений из камня или кирпича» [9]) в немалом количестве встречаются ответы типа точит камни, добывает драгоценные камни, обжигает камни, ср. реакции с имплицитными отношениями высекает статую, обрабатываem минеральы. Другой разновидностью работы деривационного механизма становится появление в реакциях реальных (но не мотивирующих) или искусственных глаголов. Единично они отмечены в ответах детей (камнит, каменьщит), чаще - как языковая игра в ответах взрослых носителей русского языка: каменеет (2), камнит (3), каменит (2), каменует, кАмючит.

Поле реакций на стимул бортник имеет не два, а три «фокуса»: ФСА, СОА и АСА в совокупности с отказами (кроме реакций в группе гуманитариев), что естественным образом снижает долю ФСА. Лексема бортник не имеет системно-ассоциативных связей, кроме элементов опосредованного словарного толкования («тот, кто занимается бортничеством», бортничество «примитивное пчеловодство в лесу, добывание меда диких пчел и простейший уход за ними» [9]). Её производящее борть неупотребительно в современном литературном языке: последняя по времени его фиксация в основном корпусе НКРЯ относится к 1937 г. [8]. Точное знание значения данного стимула ведет к системно-ассоциативному реагированию, а реакции других типов свидетельствуют об отсутствии слова в лексиконе испытуемых. Материал показывает, что слово бортник находится на периферии словарного запаса информантов: лексикографически верные ответы составили $28,6 \%$ у преподавателей, $12,9 \%$ у студентов-гуманитариев, 10,3 и $17,4 \%$ у медиков, $0 \%$ у школьников. В условиях появления незнакомого слова тактики реципиентов разделились. Часть гуманитариев (9) и медиков (3) отказываются от поиска значения и выдают реакции, которые просто не нарушали бы смысловой целостности контекста (обрабатывает дерево, следит, собирает грибы и ягоды в намем лесу и др.). Отсутствие в этом случае обращения к морфемному составу слова объяснимо: ни значение «верхний край боковой стенки судна», ни значение «левый или правый край одежды» [9] не соответствуют описываемой в тексте ситуации. Некоторым удаётся вспомнить узуальный однокоренной глагол бортничать (4). Большинство испытуемых делают попытки вычленить производящее. Эта операция у одних информантов проходит формально, автоматически, у других - осмысленно. В первом случае в ответах появляются искусственные глаголы (как того требует синтаксический контекст): бортует (10), бортирует (3), бортит (2), бортмит, бортает, бортанул, бортничествует. Такие ответы особенно часты $(31,3 \%)$ у медиков, для которых русский язык родной. К этому же виду реакций можно отнести и «ослышки»: собирает, убирает (2), бурит, борит, ср. реакцию с имплицитной связью чистит. В искусственных глаголах, отмеченных у филологов (5), можно усмотреть языковую игру, так как они представлены в анкетах, содержащих и другие «маркеры игры». В случае сознательного выбора воз- 
можного мотиватора наблюдаются попытки объяснить его связь с производным; реакции в этом случае могут быть как деривационными, так и системноассоциативными по отношению к мнимому производящему. Такая тактика особенно типична для шестиклассников (32\% ФСА, $12 \%$ СОА). Роль производящего приписывается лексеме борт в разных значениях. Примеры ФСА на мнимый мотиватор, в том числе с имплицитной связью: красит и строит бортики, водит бортовой уазик, портной, стоит на борту и спасает людей. Примеры СОА: шубы шьет, мореплаватель, делает корабли, ловит рыбу, делает воротники. Второклассники и студенты, для которых русский язык неродной, чаще придерживаются тактики отказов.

Рассмотрим поля реакций на стимулы сонатина и стеклярус (табл. 4). Оба стимула низкочастотны (1 и 2 вхождения в устный подкорпус НКРЯ [8]), не встречаются в [10], в [9] толкуются через свои производящие: «небольшая, несложная по разработке соната», соната - «инструментальное музыкальное произведение, состоящее из четырех или трех различных по темпу и характеру частей»; «род крупного бисера - разноцветные короткие трубочки из стекла, нанизываемые на нитку», бисер - «бусинки со сквозным отверстием». Таким образом, для лексемы стеклярус устанавливается системноассоциативная связь со словом бисер (имплицитно также бусины), для лексемы сонатина - со словосочетанием музылкальное произведение (имплицитно, возможно, музыка, мелодия). Контексты, в которых предъявлены стимулы, не обладают свойствами ЛДК, поэтому невысокий процент ФСА предсказуем. Поля реакций отражают в данном случае позицию реципиента в условиях, приближенных к естественным.

\begin{tabular}{|c|c|c|c|c|c|c|c|c|c|c|c|c|}
\hline \multirow[b]{3}{*}{ Группа } & \multicolumn{12}{|c|}{ Стимул } \\
\hline & \multicolumn{6}{|c|}{ стеклярус } & \multicolumn{6}{|c|}{ сонатина } \\
\hline & ш2 & ш6 & 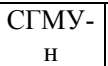 & $\begin{array}{c}\text { СГМУ- } \\
\text { p }\end{array}$ & СГУ & $\begin{array}{c}\text { Взрос- } \\
\text { лые }\end{array}$ & ш2 & ш6 & $\begin{array}{c}\text { СГМУ- } \\
\mathrm{H}\end{array}$ & $\begin{array}{c}\text { СГМУ- } \\
\text { p }\end{array}$ & СГУ & $\begin{array}{c}\text { Взрос- } \\
\text { лые }\end{array}$ \\
\hline $\begin{array}{c}\text { ФСА } \\
\text { экспл. }\end{array}$ & 68 & 64 & 26,1 & 41,4 & 32,3 & 33,3 & - & 12 & - & 3,4 & 3,3 & 23,8 \\
\hline $\mathrm{COA}$ & - & 12 & 8,7 & 10,3 & 41,9 & 23,8 & - & 24 & 39,1 & 20,7 & 36,7 & 42,9 \\
\hline KOA & 20 & 16 & 21,7 & 34,5 & 25,8 & 28,6 & 72 & 52 & 34,8 & 55,2 & 43,3 & 23,8 \\
\hline ACA & - & - & 13 & - & - & 4,8 & - & - & - & - & 10 & 4,8 \\
\hline ФA & - & - & - & - & - & - & - & - & - & - & 3,3 & 4,8 \\
\hline Отказы & 12 & 8 & 30,5 & 13,8 & - & 9,5 & 28 & 12 & 26,1 & 20,7 & 3,3 & - \\
\hline
\end{tabular}

Полученный материал отразил, в первую очередь, степень известности слов-стимулов участникам эксперимента. Школьникам и медикам с родным русским лексемы сонатина и стеклярус незнакомы, однако при наличии производящего в активном словаре (стекло, стеклянный) срабатывает деривационный механизм и возрастает доля ФСА; при отсутствии производящего в активном лексиконе (соната) преобладают КОА; в обоих случаях существенна доля отказов. Примеры: стеклярус - стекло / стёкла (30), стекляшки, стёкльшки (3), стекольщик (2), бисер (2), бусины; сонатина - соната (3), маленькая соната, музыкальное произведение (3), стиль музыки (2), мелодия (3). Сходная тактика выявляется и у студентов с неродным русским, однако деривационный механизм срабатывает слабее и доля отказов больше. Приме- 
ры: стеклярус - стекло (2), стеклодув (2), стеклоделие, гирлянды, дизайн, что-то; сонатина - музыка (5), мелодия (3), инструмент (4), скрипка (2), палка, тайна. В лексиконе гуманитариев слова стеклярус и сонатина присутствуют, что ведет к распределению реакций между ФСА, СОА и КОА. Приблизительное знание значения стимулов порождает СОА: стеклярус бисер (5), маленькие и большие прозрачные бусины; сонатина - музыкальное произведение (9), пьеса (3), его любимая музыка. ФСА представляют собой попытки, не всегда удачные, сформулировать значение слова с опорой на производящее: стеклярус - стеклянные бусины (2), изделия из стекол, прибор для выплавки стекла; сонатина - соната (3), маленькая соната (3). КОА составляют существенный пласт в ответах всех групп испытуемых. Семантически они сравнительно однородны. Для стимула стеклярус выделяется тематическая группа «украшение», эксплицитно задаваемая ближайшим контекстом, для стимула сонатина - тематическая группа «игра на скрипке», также определяемая контекстом. Примеры: стеклярус - украшение (9), красиво, сверкающие камушки, наклейки; сонатина - скрипка (24), музыкальный инструмент (12), инструмент (2), смычок (6), палка для скрипки (4), ноты, чехол для скрипки.

Обобщим тактики разных групп информантов в процессе восприятия узуальных стимулов. Школьники 2 класса на стимулы из своего активного словарного запаса (лётчик, водитель, выключатель) дали преимущественно СОА (для стимула лётчик СОА, по сути дела, совпадают с ФСА), что говорит о незначимости деривационных отношений для детей этого возраста. На стимулы малознакомые или незнакомые, но содержащие хорошо знакомую корневую морфему (каменщик, старьёвщик, скрипач, стеклярус) были предложены в основном ФСА, однако вследствие идиоматичности внутренней формы полученное деривационным путем «значение» слова не всегда совпадает с узуальным (старьёвщик «старый», каменщик «исследует камни», скрипач «скрипит»). К КОА второклассники прибегают в случае затруднений, возникающих с деривационными формулировками (каменщик), или при незнакомости корневой морфемы (сонатина). Преобладание отказов зафиксировано только для стимула бортник, значение которого не может быть выведено ни из внутренней формы (не все смогли вычленить даже мнимое производящее борт), ни из контекста.

Школьники 6 класса и медики, для которых русский язык является родным, предпочли в эксперименте ФСА как на хорошо знакомые стимулы, так и на мало знакомые и незнакомые, содержащие знакомый корень. Иногда деривационный механизм срабатывал даже при неизвестном корне, но стандартной словообразовательной модели (бортник - бортует), а также вопреки реальным мотивационным отношениям (скрипач - скрипит, каменщик каменит). В случаях расхождения системных и деривационных ассоциаций (водитель, скрипач) в полях реакций появлялся дополнительный «фокус» СОА. Приоритет ФСА в ущерб СОА объясним у шестиклассников активной фазой изучения словообразовательных отношений в школьной программе, у студентов - аналогией к ближайшему контексту-образцу (летчик - летает, учитель - учит). Отказы, хотя и не стали нигде преобладающей формой ответов, составили довольно значительный процент в полях стимулов, находя- 
щихся на периферии индивидуальных лексиконов испытуемых (сонатина, бортник, стеклярус).

Тактика речевого поведения в эксперименте тех студентов, для которых русский язык не является родным, производит впечатление «наименьшего сопротивления»: там, где возможно, даются однословные ответы (70,9\%), независимо от типа реакции. Так, для стимулов лётчик, водитель, старьёвщзик однословные реакции принадлежат к ФСА (летает, водить, старый), для стимулов каменщик, сонатина - к СОА (строит, музыка). Исключение делается для стимула скрипач (играет, скрипит и играет на скрипке). Для незнакомых слов (стеклярус, бортник) предпочитаются отказы или АСА. На знакомый стимул выключатель, находящийся, однако, в слабой позиции, получены в основном КОА.

Для студентов-гуманитариев ФСА не стали в нашем эксперименте приоритетными. Они существенно преобладают только в мотивационно ориентированном контексте стимула старьёвщик и там, где направление деривации поддерживается системными ассоциациями (лётчик). В полях реакций на остальные стимулы, как хорошо знакомые и прозрачные в отношении ВФ, так и дефектно членимые, наряду с деривационным отчетливо выделяется «фокус» СОА. КОА играют заметную роль в ответах на стимулы бортник и сонатина, периферийные в индивидуальных лексиконах, и стимул выключатель, находящийся в слабой контекстной позиции. Не исключено, что причина отказа от ФСА кроется в усвоенном со школьных времен «правиле»: повторение однокоренных слов в том же или соседнем предложении - стилистическая ошибка. В то же время факт апелляции к этому «правилу» говорит об осознанном выборе средств выражения мысли, об активизации у испытуемых механизмов контроля речевого поведения.

Для филологов старшего поколения среди предъявленных стимулов не оказалось совершенно незнакомых, однако в большинстве случаев (лётчик, скрипач, старьёвщик, стеклярус) приоритет был отдан ФСА, иногда (водитель, выключатель) - с широко представленными имплицитными отношениями. Очевидно, причина появления ФСА в этом случае иная, чем у детей: не попытка осмыслить значение малознакомого или незнакомого слова исходя из его внутренней формы, а профессиональная привычка формулировать значение слова с опорой на производящее. Именно опорой на словарное толкование, не содержащее мотиватора или содержащее мотиватор в слабой синтаксической позиции, можно объяснить наличие «фокуса» СОА в полях реакций на стимулы бортник, каменщик, стеклярус. В данном случае, как и в ответах студентов-гуманитариев, доминирует установка на контролируемое речепорождение, однако она принимает вид рефлексии не над текстом как коммуникативным целым, а над словом как единицей лексической системы. Невозможность отразить в ответе словообразовательное значение аффикса (стеклярус, сонатина) вела к появлению «фокуса» КОА.

Перейдем к анализу реакций на неузуальные стимулы. Соотношение разных типов реакций на свободно членимые стимулы представлено в табл. 5, 6 . Преобладание ФСА очевидно. Реакции на стимулы Баранкин и Копалкин у взрослых носителей русского языка демонстрируют некоторое смещение в сторону блока СОА (любишь в песке возиться, не расстаешься с лопатой, 
любишь сажать, археолог, садовник, всё время что-то ищешь; кругльй, плюшка, обжора, глупьй), а у студентов-гуманитариев - также КОА (mbl cblн Баранкиных ; большой, пушистый). Отсутствие подобной «оттяжки» у стимула зонтарь обусловлено синтаксическими свойствами контекста (структура фразы однозначно предполагает название предмета-результата действия). Представляет интерес довольно значительная доля отказов среди ответов на стимул красари. Не исключено, что она связана со слишком большим количеством возможных мотиваторов и, следовательно, с трудностью выбора.

\begin{tabular}{|c|c|c|c|c|c|c|c|c|c|c|c|c|}
\hline \multirow[b]{3}{*}{ Группа } & \multicolumn{12}{|c|}{ Стимул } \\
\hline & \multicolumn{6}{|c|}{ зонтарь } & \multicolumn{6}{|c|}{ красари } \\
\hline & ш2 & ш6 & \begin{tabular}{|c|} 
СГМУ- \\
H
\end{tabular} & \begin{tabular}{|c|} 
СГМУ- \\
p
\end{tabular} & СГУ & $\begin{array}{c}\text { Взрос- } \\
\text { лые }\end{array}$ & ш2 & ш6 & $\begin{array}{c}\text { СГМУ- } \\
\text { н }\end{array}$ & $\begin{array}{c}\text { СГМУ- } \\
\mathrm{p}\end{array}$ & СГУ & $\begin{array}{l}\text { Взрос- } \\
\text { лые }\end{array}$ \\
\hline $\begin{array}{c}\text { ФСА } \\
\text { экспл. }\end{array}$ & 68 & 92 & 60,9 & 93,1 & 93,5 & 95,2 & 84 & 64 & 56,5 & 72,2 & 79,3 & 61,9 \\
\hline $\begin{array}{r}\text { ФСА } \\
\text { импл. }\end{array}$ & - & - & - & - & - & - & - & - & 8,7 & - & - & 4,8 \\
\hline $\mathrm{COA}$ & - & - & 4,3 & - & - & - & - & 16 & 4,3 & 3,4 & 6,9 & - \\
\hline $\mathrm{KOA}$ & 12 & - & - & - & 3,2 & 4,8 & 4 & 16 & 4,3 & - & 3,4 & - \\
\hline$\Phi A$ & 8 & - & - & - & - & - & - & - & - & - & - & 9,5 \\
\hline ACA & 4 & 4 & 8,7 & 6,9 & 3,2 & - & - & 4 & 8,7 & 3,4 & 10,3 & 9,5 \\
\hline Отказы & 8 & 4 & 26,1 & - & - & - & 12 & - & 17,4 & 20,7 & - & 14,3 \\
\hline
\end{tabular}

Таблица 6

\begin{tabular}{|c|c|c|c|c|c|c|c|c|c|c|c|c|}
\hline \multirow[b]{3}{*}{ Группа } & \multicolumn{12}{|c|}{ Стимул } \\
\hline & \multicolumn{6}{|c|}{ Баранкин } & \multicolumn{6}{|c|}{ Копалкин } \\
\hline & ш2 & ш6 & $\begin{array}{c}\text { СГМУ- } \\
\text { н }\end{array}$ & $\begin{array}{c}\text { СГМУ- } \\
\mathrm{p}\end{array}$ & СГУ & $\begin{array}{c}\text { Взрос- } \\
\text { лые }\end{array}$ & ш2 & ш6 & $\begin{array}{c}\text { СГМУ- } \\
\text { н }\end{array}$ & $\begin{array}{c}\text { СГМУ- } \\
\mathrm{p}\end{array}$ & СГУ & $\begin{array}{c}\text { Взрос- } \\
\text { лые }\end{array}$ \\
\hline $\begin{array}{c}\text { ФСА } \\
\text { экспл. }\end{array}$ & 88 & 96 & 69,6 & 70 & 71 & 79,2 & 92 & 92 & 58,3 & 82,8 & 75 & 72,7 \\
\hline $\begin{array}{c}\text { ФСА } \\
\text { импл. }\end{array}$ & - & - & 4,3 & - & 3,2 & 4,2 & - & - & - & 3,4 & 3,6 & 4,5 \\
\hline $\mathrm{COA}$ & - & - & 4,3 & 23,3 & 16,1 & 16,7 & - & 4 & - & 6,8 & 14,3 & 13,6 \\
\hline $\mathrm{KOA}$ & - & - & 13 & - & 9,7 & - & - & - & 12,5 & - & 7,1 & - \\
\hline$\Phi \mathrm{A}$ & - & - & - & - & - & - & - & 4 & 20,8 & - & - & 9 \\
\hline $\mathrm{ACA}$ & 8 & - & 8,7 & 3,3 & - & - & - & - & 4,2 & 3,4 & - & - \\
\hline Отказы & 4 & 4 & - & 3,3 & - & - & 8 & 4 & 4,2 & 3,4 & - & - \\
\hline
\end{tabular}

Рассмотрим особенности вычленения мотиваторов разными группами информантов. Для стимула зонтарь предлагается только вариант зонты / зонтики. В отношении остальных стимулов предположения испытуемых расходятся. Для стимула Копалкин абсолютное большинство информантов признаёт мотиватором глагол копать и лишь немногие гуманитарии $(8,3 \%$ преподавателей и $14,2 \%$ студентов) - глагол копаться «медленно делать»: копуша, копаешься долго (4). Для стимула Баранкин фиксируются три возможных мотиватора: баран, баранка «руль», баранка «бублик». Второклассникам и студентам с неродным русским метафора баранка «руль» незнакома, они выбирают преимущественно мотиватор баран (52 и $52,2 \%$ ), который с формальной точки зрения не может являться производящим; очевидно, в языковой практике этих испытуемых данная лексема встречается чаще, чем баранка «бублик». Шестиклассники и преподаватели предпочитают мотиватор баранка «бублик» (48 и 33,3\%): на баранку похож, любишь баранки, пе- 
чёшь баранки. Студенты-гуманитарии колеблются между мотивациями «бублик» и «руль» (по 32,3\%): баранку целыми днями крутишь, а по вечерам с ними чай пьёшь. В ответах студентов-медиков с родным русским все предполагаемые мотиваторы представлены примерно в равных долях. Кроме перечисленных, встретилось несколько индивидуальных осмыслений мотивационных отношений: в бараньей шапке, пастух, кудрявкин, одет как смешарик Бараш.

Особенно много возможных мотиваторов фиксируется для лексемы красари. Здесь можно выделить несколько видов семантической связи производящего с производным. Значение «лицо, производящее действие»: красят (42), раскрашивают, украшают, красятся; реакции с имплицитной связью: pисуют, маляры. Данный словообразовательный тип выделен в [11. С. 147] как непродуктивный. Значение «лицо по продукту деятельности» (продуктом в нашем случае выступает красота): красиво косят, красоту наводят, красавиц наряжают; реакции с имплицитной связью: косметикой занимаются, делают мир лучще, цветочники. Данный словообразовательный тип в [11. С. 188] рассматривается как продуктивный, ср. стимул зонтарь. Значение «лицо, характеризующееся признаком, названным производящим прилагательным»: красивые (12), красавиы, красутки, красные. Данный словообразовательный тип в [11] не фиксируется, однако в литературном языке можно найти несколько слов, образованных таким способом: дикарь, главарь, ср. глухарь, сухарь. Значение «лицо, испытывающее состояние, названное производящим глаголом»: красуются (16), краснеют; возможно, в эту группу следует включить искусственный глагол красуют (10). Данный словообразовательный тип в кодифицированном языке отсутствует. Выбор мотивации соотносится с возрастом и специальностью испытуемых. Так, словообразовательный тип с производящим прилагательным отмечен только у школьников ( $24 \% 2$ кл., $28 \% 6$ кл.); второклассники, выделившие в качестве производящего глагол, предпочли мотиватор красить (28\%), шестиклассники - красоваться (16\%). В ответах студентов стимул интерпретируется, за исключением единичных реакций, как отглагольный. При этом медики, для которых русский язык не является родным, из реальных производящих оказались способны вычленить только красить (34\%), а при затруднениях образовывали искусственное красовать (13\%). Медики, для которых русский язык родной, выделяли два реальных глагола: красить $(24,1 \%)$ и красоваться $(17,2 \%),-$ и искусственный красовать $(13,8 \%)$. У гуманитариев сложностей с подбором мотивирующего глагола не возникло, предпочтение было отдано узуальному словообразовательному типу: красить - 48,3\%, красоваться - 17,2\%. Ответы преподавателей поровну $(23,8 \%)$ распределились между узуальными словообразовательными типами с производящими красить и красота. Кроме того, в ответах информантов всех групп имеются «ослышки»: ловят карасей (2), ловят рыбу (2) - ассоциация на караси, крыс ловят, ну и мылшей по праздникам, следят за кротами, кроссируют, плавают. Есть и примеры перспективной деривации: красарят (5), красарируют.

Перейдем к анализу реакций на неузуальные стимулы с дефектной членимостью (табл. 7). В полях реакций на стимулы шишенята и земличные преобладают ФСА, в поле стимула загандёр два «фокуса»: ФСА и КОА, причём 


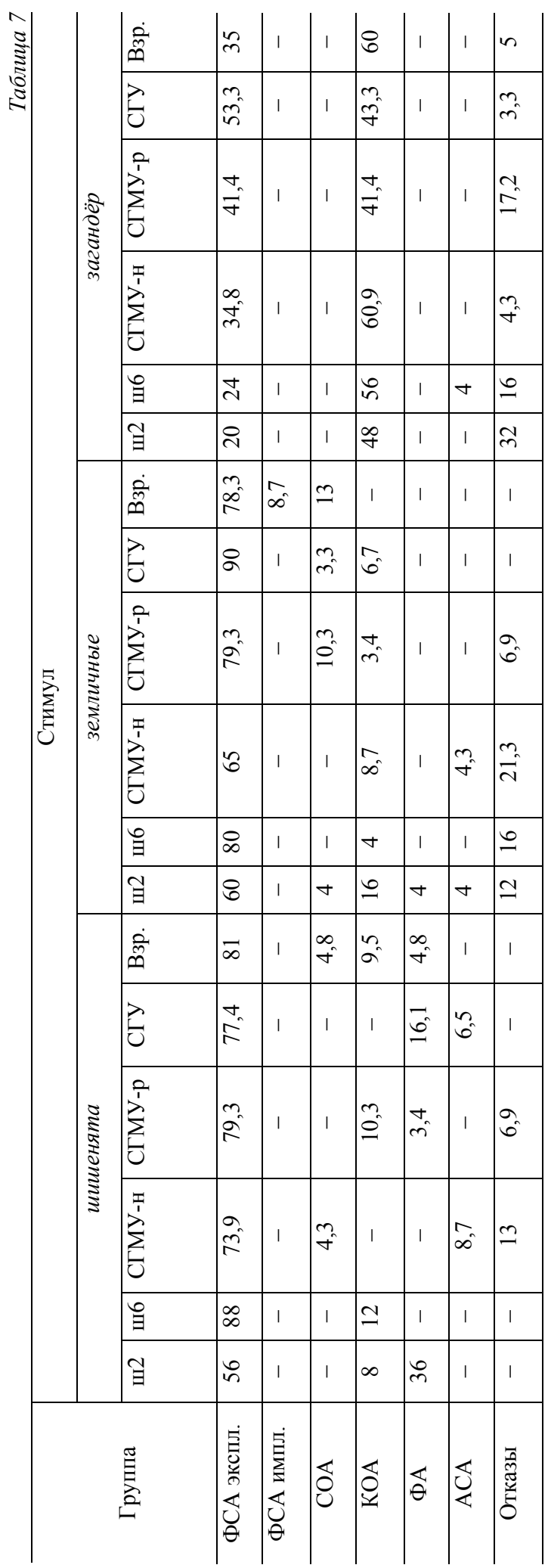


второй у большинства испытуемых является основным. Такая ситуация, по нашему мнению, связана с морфонологической структурой стимулов: у лексем шишенята и земличные трансформация морфем может быть интерпретирована как усечение или наращение, что типично для словообразовательной морфонологии русского языка, тогда как в слове загандёр попытки вычленить узуальную корневую морфему требуют введения инфиксации или чередований, не характерных для русской морфонологической системы.

В структуре словоформы шишенята неясна принадлежность отрезка -енкорню или суффиксу. При первой трактовке получаем неузуальный корневой морф, соединенный с узуальным суффиксом невзрослости. В этом случае ФСА предполагает выражение семантики суффикса, эксплицитное или имплицитное, и интерпретацию корневого морфа как обозначающего живое существо. В нашем материале интерпретация корня основана в большинстве случаев на фонетических ассоциациях. Примеры: щенята (6), щенки (2), мышата, маленькие шиншиллы (2), мальши (2), маленькие существа. Противоречие между формальным требованием словообразовательного типа (одушевленность производящего) и неодушевленностью вычленяемого мотиватора шиики у преподавателей и студентов-гуманитариев часто разрешается при помощи метафоры: шишкины дети (5), дети больших шишек. Суффикс ят(a), согласно [11. С. 215], может иметь переносные значения. В реакциях наших испытуемых таковыми стали значения уменьшительности, ласкательности и подобия, отсутствующие в узусе: маленькие шишки (10), шишечки (2), маленькие шишечки (2), щеночки; милые создания, смешные зверюшки; похожсие на шишки существа, колючие шишкообразные объекты, шишковидные шишки, похожи на шишки (3), похоже на щенков. Такой способ реагирования особенно широко представлен в ответах медиков, для которых русский язык родной. При второй трактовке констатируется неузуальный алломорф суффикса, что затрудняет идентификацию суффиксальной морфемы. В этом случае ФСА затрагивает только корневую морфему. Пренебрегают значением суффикса и реагируют только на корень (шишки) чаще школьники (29), несколько реже - медики (21), единично - филологи (2). Гуманитарии, рассматривающие суффиксальный морф как неузуальный, предлагают разнообразные интерпретации мотивационных отношений: под шишняком растут; под иишками лежат; везде собирают шиики; зверьё, которым я шишки набил. Таким образом, трактовка стимула как структуры «узуальный корень + аффикс, уникальный по форме и/или семантике» во всех группах испытуемых явилась преобладающей. Несколько раз стимул был интерпретирован как отглагольный с фонетической ассоциацией на корень: шилят, шуршат, шушукают, шишинят. Встретились также ФА, не выражающие деривационных отношений: шиншилль (10), ежи, едят шины.

Стимул земличные является неузуальным, но потенциальным словом в системе русского языка. С формальной точки зрения он мог бы быть образован от лексемы землица, относящейся к пассивному лексикону большинства испытуемых. Вследствие этого основным мотиватором для данного стимула в нашем материале явилось слово земля. Отношения производного к производящему интерпретировались при помощи разных глаголов: в земле живут, на земле валялись, землёй пахнут, едят землю и т.п. Только в одном ответе 
мотиватором признано прилагательное: ивет у них земляной; возможно, таковы же и реакции с имплицитными отношениями серые и черные. Мотиватор земля порождает и СОА: живут в норках, на кротов похожи, любят ползать, растут под соснами, опали рано, грязные. В тех ответах, где основой ассоциирования стал суффиксальный морф, мотиватор интерпретировался как земляника (13): землянику любят (2), из земляники сделаны, вкусняики земляничные, едят землянику (4), розовые, как земляничка, сладкие и т.п.

Наибольшие трудности вызвал у информантов поиск производящего или мотиватора для слова загандёр. Из реальных глаголов были предложены загадывать (3), ср. загадки (2), загонять (9), гундеть / гундить (7), галдеть (2), загорать. Представляет интерес высокая частота мотиватора загонять, который не соответствует узуальному словообразовательному типу существительных на -ёр, однако в современном молодёжном жаргоне имеет значение, близкое к действию, производимому персонажем текста: «сочинять, придумывать, шутя, говорить о чем-то невероятном» [12]. В то же время у филологов: загонять музыку, загонять гвозди, загонять всех в угол. Большинство искусственных образований вписывается в продуктивный словообразовательный тип \{усеченная основа глагола + суффикс -ёр $\}$ со значением «лицо, производящее действие», выделяемый в [11. С. 148]: загондировать (10), загондовать, загундивать, загондить / загандить (6). Отступают от этого типа гондарить, гундерить, гондонить, предполагающие приставочносуффиксальный способ образования. Перспективные дериваты: загондёрывать / загондёривать (3), загондёрничать, загандирИть, загондерить; возможно, к этой же группе можно отнести загандурить всех (сложение с дуpuть?). Таким образом, большинство «однокоренных» слов к стимулу загандёр реализует узуальные продуктивные словообразовательные типы. Отступления делаются в пользу соответствия значения слова описываемой ситуации. КОА на стимул загандёр называют действия, каузировавшие описываемую ситуацию: шутить (14), смешить (25), веселить (11), рассказывать веселье / смешные истории / сказки (4), развлекать и т.п.

Поля реакций на неузуальные сложения представлены в табл. 8. Картина получилась неодинаковой за счёт неравноценности деривационного потенциала контекстов. Синтаксическая структура контекста стимула гудыметь допускает повтор заданного глагола, который и имеет место в ответах почти половины испытуемых. Однако если исключить повтор, то ФСА преобладают над остальными в поле стимула гудылеть так же, как и в поле нетамыгранџы. Исключение составляют ответы школьников на стимул нетамыгранu̧bl, который дети не смогли интерпретировать.

\begin{tabular}{|c|c|c|c|c|c|c|c|c|c|c|c|c|}
\hline \multirow[b]{3}{*}{ Группа } & \multicolumn{12}{|c|}{ Стимул } \\
\hline & \multicolumn{6}{|c|}{ нетамьгграниьы } & \multicolumn{6}{|c|}{ гудымметь } \\
\hline & ш2 & ш6 & $\begin{array}{c}\text { СГМУ- } \\
\text { н }\end{array}$ & \begin{tabular}{|c|} 
СГМУ- \\
$\mathrm{p}$
\end{tabular} & СГУ & $\begin{array}{c}\text { Взрос- } \\
\text { лые }\end{array}$ & ш2 & ш6 & $\begin{array}{c}\text { СГМУ- } \\
\text { H }\end{array}$ & $\begin{array}{c}\text { СГМУ- } \\
\text { p }\end{array}$ & СГУ & $\begin{array}{c}\text { Взрос- } \\
\text { лые }\end{array}$ \\
\hline ФСA & - & 8 & 47,7 & 82,7 & 83,3 & 81 & 32 & 42,2 & 20 & 48,2 & 23,3 & 40,9 \\
\hline KOA & 36 & 52 & 17,4 & 13,8 & 3,3 & 14,3 & 24 & 11,5 & 16 & 10,3 & 6,7 & 9,1 \\
\hline Повтор & - & - & - & - & - & - & 40 & 46,2 & 64 & 37,9 & 70 & 50 \\
\hline ФА & 16 & 12 & 13 & - & 6,7 & - & 4 & - & - & 3,4 & - & - \\
\hline ACA & 8 & 4 & 4,3 & - & 6,7 & - & - & - & - & - & - & - \\
\hline Отказы & 40 & 24 & 17,4 & 3,4 & - & 4,8 & - & - & - & - & - & - \\
\hline
\end{tabular}


Теоретически для двухкорневого стимула возможны три варианта восприятия с опорой на деривационные отношения: распознаётся только первое производящее (1), только второе (2), оба (3). В нашем материале для стимула гудыметь преобладающим оказался первый вариант (от 16 до 34,5\%). В большинстве ответов (27) производящее гудеть оказалось представлено эксплицитно, но отмечены и реакции с имплицитным характером связи: шуметь (4), издавать звуки (2), бибикать, жужжать на всю округу. Вариант с вычленением только производящего дымить встретился 5 раз у медиков, 3 у гуманитариев, 1 - у шестиклассников. Оба производящих (гудеть $u$ дымить) сумели вычленить только два преподавателя и один шестиклассник. КОА формируют семантические группы «функционировать» и «функционировать с неисправностями»: ездить / ехать (6), работать (3), двигаться, заводиться; ломаться (4), барахлить, всегда работать исправно.

Мотиваторы стимула нетамыгранцы оказались хорошо распознаны взрослыми носителями русского языка, несколько хуже - теми, для кого русский язык не является родным. Среди детей только двое шестиклассников дали ФСА: играют не там и нетамыгранят. Основным вариантом ФСА стало вычленение обоих производящих: не там играют (47); реакции с частично или полностью имплицитным характером связи: играют где хотят, играют в неположенном месте / местах (3), играют где попало, играют на дороге и мешают ехать, бегают где попало. Что касается семантики КОА, то отмечается интересный факт: реакции взрослых либо нейтральны, либо положительно окрашены (гуляют, поют, весёлье и т.п.), а в реакциях детей преобладает отрицательная коннотация (тупье, дикие, задерживают, грабят, нарушают ПДД и т.п.). Вероятно, такую оценку породила неспособность увидеть мотиватор играть, который мог бы придать ассоциациям положительный «эмоциональный заряд». В результате ситуация была интерпретирована с опорой на жизненный опыт реципиентов, где появление на дороге незнакомцев не предвещает ничего хорошего. Взрослые оценивали описываемую ситуацию с опорой на текст как целое, поэтому предпочли «добрую сказку».

Сопоставление особенностей ФСА на стимулы гудыметь и нетамыгранuъbl позволяет заметить, что на успешность вычленения производящего влияет не место его в структуре сложного слова, а собственные свойства. Так, количество фиксаций в устном подкорпусе НКРЯ [8] составляет для дымить 27, а гудеть - 75; в [10] гудеть дает реакции шуметь (7) и машина (4), тогда как дылмить связывается преимущественно с курить (22). При наличии в кодифицированном литературном языке словообразовательного типа \{основа страдательного причастия + суффикс -ец\} со значением «лицо, названное по характерному действию» [11. С. 145] носителю языка легче вычленить в производном существительном основу производящего глагола, чем местоименный сомотиватор. Впрочем, для школьников нельзя полностью исключить и влияние порядка следования производящих основ в структуре композита: для стимула нетамыгранцы с трудно распознаваемым первым компонентом «фокус» поля реакций составили не ФСА ко второму компоненту, а КОА и отказы.

Таким образом, появление в речи неузуальных слов задействовало у наших информантов те же ментальные механизмы, что и появление слов узуальных, но малознакомых, находящихся на периферии языкового опыта, - 
механизм деривационного анализа, а в случаях затруднений с его применением - ситуативное реагирование. Основной функцией деривационного механизма стало осмысление значения незнакомых слов. Особенности поиска испытуемыми возможных производящих для предъявляемых стимулов показали, что взрослые информанты следуют в своих реакциях узуальным словообразовательным типам, отступления представлены в основном в ответах детей. Закрепленность словообразовательных типов в языковой практике испытуемых выражается и в создании по ним искусственных образований, широко представленных в ответах на те стимулы, где выбор узуального мотиватора связан с определенными трудностями (красари, загандёр). В этом случае можно говорить также о проявлении речепорождающей функции деривационного механизма, действующей на уровне словотворчества. Однако появление в речи собеседника незнакомых слов создаёт помехи в процессе общения, а умение избегать подобных помех - свойство хорошо развитой языковой личности, обладающей навыками речевого самоконтроля. Вероятно, поэтому реагирование искусственными словами чаще встречается в ответах нефилологов, у которых сформирован навык конструирования связных высказываний, но не достигнут уровень продукции коммуникативно адекватного текста. В ответах гуманитариев окказионализмам, как правило, сопутствуют маркеры игровой игры - попытка уравнять свой коммуникативный статус со статусом экспериментатора и контролировать процесс общения. КОА давались испытуемыми преимущественно на стимулы с трудно вычленимыми корневыми морфемами (загандёр и нетамыгранць)).

Итак, полученный материал показал, что потребность в активизации механизма формально-семантического реагирования обусловлена возрастом и специальностью информантов, степенью владения системой языка и структурой индивидуальных лексиконов. В свою очередь, структура поля реакций на каждый конкретный стимул определяется свойствами контекста (деривационным потенциалом, необходимостью замещения синтаксических позиций) и системными свойствами самого стимула (закрепленностью связи производного с производящим в словарях, частотностью как стимула, так и его предполагаемого мотиватора).

У учащихся 2 класса навык деривационного анализа выработан ещё недостаточно, поэтому там, где возможно, предпочитается системноассоциативное реагирование. Деривационный анализ используется только как средство выявления значения незнакомых слов или таких, значение которых известно неточно. Эта тактика иногда приводит к ошибочным интерпретациям связи производящего с производным. Опорным элементом структуры стимула становится корневая морфема, семантика же суффикса и требования словообразовательных типов, как правило, игнорируются. При возникновении трудностей в определении корня используются информация, извлеченная из контекста, суппозитивное знание, фонетическое реагирование либо отказ от ответа. Для учащихся 6 класса деривационный анализ оказался в нашем эксперименте базовым механизмом реагирования. Он «плохо срабатывал» только для слов с трудно вычленяемыми (для данной категории испытуемых) корневыми морфемами. Ограничение на ФСА накладывалось слабостью синтаксической позиции стимула в контексте. В то же время неполное владение 
словообразовательной системой русского языка проявилось у шестиклассников в обращении к неузуальным словообразовательным типам при выборе производящих для неузуальных стимулов, а также в игнорировании семантики суф-фикса.

Стратегия медиков, для которых русский язык является родным, также определяется презумпцией формально-семантического реагирования. Процент выходов деривационного типа довольно высок даже в полях реакций на стимулы выключатель (слабый деривационный потенциал контекста) и загандёр (неузуальный корень). Однако прослеживается и одно важное различие: при возникновении в языковом опыте отдельных испытуемых противоречия между формальными требованиями словообразовательного типа и семантическим правдоподобием мотивировки студенты следуют грамматической аналогии, образуя несуществующие глаголы в соответствии с узуальными словообразовательными типами (бортник - бортует, загандёр - загондировать), а школьники опираются на знание действительности, подыскивая мотиватор из своего словарного запаса, даже вопреки общему содержанию текста (бортник - борт чинит, загандёр - загорать). Значительный процент КОА появляется у студентов при невозможности вписать стимул в узуальный словообразовательный тип.

Студенты, для которых русский язык не является родным, используют деривационный анализ только в реакциях на свободно членимые стимулы, как узуальные, так и неузуальные. Как свободно членимые интерпретируются этими информантами и стимулы шишенята, земличные, нетамыграниы, корни и суффиксы которых легко идентифицируются на морфемном уровне, а неузуальность некоторых алломорфов не замечается испытуемыми. Однако любое ослабление деривационно ориентирующего потенциала контекста ведет к снижению доли ФСА и к смещению «фокуса» поля реакций в область КОА или отказов. К этому же случаю можно отнести и реакции на стимулы бортник и каменщик: структура этих лексем противоречит актуализованному в контексте образцу «имя деятеля - производящий глагол», поэтому на знакомое слово каменщик преобладают СОА (строит), а на незнакомое бортник - отказы.

Стратегией речевого поведения студентов-гуманитариев стало стремление к созданию качественного текста, что проявилось как в структуре полей реакций, так и в некоторых специфических чертах самих ответов. Реагирование однокоренными словами придаёт тексту лексическое однообразие, поэтому соответствующие ответы выбираются испытуемыми только для тех узуальных стимулов, где они неизбежны (лётчик, старьёвщик). В полях реакций на другие узуальные стимулы ФСА конкурируют с СОА. Отсутствие у экспериментального контекста достаточного деривационного потенциала или незнание точного значения слова ведет к увеличению доли КОА. При реагировании на неузуальные стимулы происходит активизация механизма деривационного анализа. В выборе мотиватора из нескольких возможных гуманитарии руководствуются, прежде всего, требованиями узуальных словообразовательных типов, однако в случае возникновения затруднений или противоречий предпочтение чаще отдаётся осмысленным высказываниям, чем искусственным словам (загандёр - загонять, гундеть; шишенята - маленькие 
шишки). Характерная черта реакций гуманитариев - развёрнутость: тенденция к заполнению сильных синтаксических валентностей глагола (веселить коротышек, копаешь клумбы), к использованию перифраз (плеваться дымом, землю Ковырялкин), подробное объяснение семантической связи производящего с производным (играют на дороге и мешают ехать), стремление представить описываемую ситуацию в целом (делает упражнения перед кониертом, несёт колоду мёда из леса). У отдельных информантов отмечается склонность к языковой игре.

Картина результатов эксперимента у филологов старшего поколения в целом сходна с картиной у студентов-гуманитариев, однако прагматические установки не совпадают. Внимание студентов обращено преимущественно к тексту как художественному целому, тогда как для преподавателей более значимы системные связи языковых единиц. Профессиональный опыт позволяет избежать лексического однообразия путём активизации системных связей стимула (синонимия, перифразы). Играет роль и разница индивидуальных лексиконов: со стороны преподавателей часто имеет место воспроизведение словарного толкования известных слов, а со стороны студентов - попытка осмыслить значение малознакомых слов с «прозрачной» внутренней формой. Преподаватели чаще, чем студенты, прибегают к языковой игре, причем игра направлена на внутреннюю форму слова, у студентов же обыгрываются преимущественно текст и стоящая за ним внеязыковая ситуация.

Таким образом, динамика функционирования деривационно-ассоциативного механизма носит следующий характер. У младших школьников деривационные связи языковых единиц еще недостаточно сформированы и не влияют на восприятие текста; ситуация эксперимента не рассматривается этими испытуемыми как сознательное речепорождение, их ассоциации близки к свободным. У детей 12-13 лет деривационные отношения находятся в фазе актуализации и выступают в роли средства интерпретации семантики малознакомых слов; в то же время усвоение словообразовательной системы языка ещё не завершено, о чём говорят ошибки в определении семантики аффиксов или её игнорирование, а также использование неузуальных словообразовательных типов. Самоконтроль над процессом порождения речи не выходит за рамки заботы о правильности и осмысленности предложения; прагматическая установка на получение адекватного текста не накладывает ограничений на работу деривационного механизма. К 17-18 годам происходит полное овладение словообразовательными нормами языка, однако с расширением словарного запаса деривационно-ассоциативный механизм утрачивает у информантов активную когнитивную функцию. С этого возраста наблюдаются различия речепорождающих функций деривационного механизма, определяемые специальностью и личностными особенностями информантов. Медики ориентированы на продуцирование фраз, соответствующих нормам и образцам (роль деривации - создание необходимых заполнителей синтаксических позиций), студенты-гуманитарии - на создание текста как целостного художественного произведения (действие деривационных ассоциаций сознательно ограничивается), филологи старшего поколения актуализируют разнообразные системные связи лексических единиц, активно прибегая к языковой игре (деривационные ассоциации играют роль метатекстовых рефлексивов). 


\section{Лuтература}

1. Голев Н.Д. Деривационные ассоциации русских слов: теоретический и лексикографический аспекты // Вопр. лексикографии. 2012. № 2. С. 5-25.

2. Аввакумова E.A. Морфематические основания интуитивной орфографии русского языка (на материале эксперимента с детьми 6-7 лет): дис. ... канд. филол. наук. Барнаул, 2002. 170 с.

3. Бринев К.И. Внутренняя форма слова как носитель потенциала его деривационного функционирования: дис. ... канд. филол. наук. Кемерово, 2002. 144 с.

4. Доронина Н.И. Деривационные ассоциации слов русского языка: лексикографический и теоретический аспекты: дис. ... канд. филол. наук. Барнаул, 1999. 133 с.

5. Сайкова Н.В. Взаимодействие слова и текста в деривационном аспекте (на материале вторичных текстов разных типов): дис. ... канд. филол. наук. Барнаул, 2002. 163 с.

6. Горелов И.Н., Седов К.Ф. Основы психолингвистики. М.: Лабиринт, 2001. 304 с.

7. Голев Н.Д. Мотивационно-ассоциативный словарь русского языка: теоретические основания и лексикографическая концепция // Вестн. Том. гос. ун-та. 2011. № 3 (15). С. 17-30.

8. Национальный корпус русского языка [Электронный ресурс]. URL: http:// www. ruscorpora.ru/search-spoken.html (дата обращения: 02.02.2016).

9. Словарь русского языка: в 4 т. / под ред. А.П. Евгеньевой. М.: Рус. яз., 1985-1988.

10. Русский ассоциативный словарь [Электронный pecypc]. URL: http://tesaurus.ru/dict/ dict.php (дата обращения: 02.02.2016).

11. Русская грамматика. М.: Наука, Т. 1. 1980. 784 с.

12. Словарь молодежного слэнга [Электронный ресурc]. URL: http://teenslang.su/ content/ ГН?novar=1 (дата обращения: 02.02.2016).

\section{FUNCTIONING OF THE DERIVATIONAL-ASSOCIATIVE MECHANISM IN THE PER- CEPTION OF THE TEXT (AN EXPERIMENTAL STUDY)}

Vestnik Tomskogo gosudarstvennogo universiteta. Filologiya - Tomsk State University Journal of Philology. 2017. 45. 45-69. DOI: 10.17223/19986645/45/3

Natalia I. Danilina, Saratov State Medical University (Saratov, Russian Federation). E-mail: danilina_ni@mail.ru

Keywords: associative experiment, text, derivation.

The article presents an experiment on elicitation of real and novel words in lexical-derivational contexts within a coherent text. The informants were school children 8 and 12 y.o., medical students and linguistic students, university lecturers 30 y.o. and older (a total of 153 people). There were produced more than 2800 answers. The result of the experiment makes it possible to identify the place of derivational associations in the process of speech perception and to consider the impact of various systemic and sociolinguistic factors.

Age dynamics of derivation association is as follows. The younger pupils do not have enough derivational skills to affect the perception of the text. In children of 12-13 years of age derivational relations are being formed and act as a means of interpretation of semantics of both known and unknown words. At this age the word-formation system of individual language is not yet complete, which is attested by misinterpretation or neglect of affixal semantics, by the erroneous identification of the formal producing base, the use of occasional word-formation types. By the age of 17-18 the wordformation rules of the language have been mastered, but the derivational-associative mechanism loses its active cognitive function in line with the vocabulary expansion. Medical students as well as sixth graders use derivational response as their default strategy. However, when there is disagreement between the formal requirements of the word-formation type and semantic motivational plausibility, the students follow the grammatical analogy, forming innovative verbs according to usage-based wordformation types, and the children draw upon their knowledge of reality and search their vocabulary for a motivated word.

The difference in the responses according to their study major or special field observed with college-age informants. Medical students do not show interest in the background text, and more closely follow relevant standards and samples in their phrase elicitation. Humanities majors aim to create a coherent literary text. This tendency manifests itself in the structure of the reaction fields of art students, and in the following specific features: obligatory filling of strong syntactic valencies of the verb, 
using a paraphrase, explaining the semantic connection of the derivative and the producing base, general reflection on the situation described. Experienced philologists attribute more meaning to a wide (not only derivation) variety of systemic word relations. Compared to students, the lecturers are more into language game, their game aimed a word form, while the students also make play around the entire text, and the extra-linguistic situation behind it.

\section{References}

1. Golev, N.D. (2012) Derivational associations of Russian words: theoretical and lexicographical aspects. Voprosy leksikografii - Russian Journal of Lexicography. 2. pp. 5-25. (In Russian).

2. Avvakumova, E.A. (2002) Morfematicheskie osnovaniya intuitivnoy orfografii russkogo yazyka (na materiale eksperimenta s det'mi 6 - 7 let) [Morphematic bases of intuitive spelling of the Russian language (on the material of the experiment with children aged 6-7)]. Philology Cand. Diss. Barnaul.

3. Brinev, K.I. (2002) Vnutrennyaya forma slova kak nositel' potentsiala ego derivatsionnogo funktsionirovaniya [The inner form of the word as a potential of its derivational functioning]. Philology Cand. Diss. Kemerovo.

4. Doronina, N.I. (1999) Derivatsionnye assotsiatsii slov russkogo yazyka: leksikograficheskiy $i$ teoreticheskiy aspekty [Derivational associations of Russian words: lexicographic and theoretical aspects]. Philology Cand. Diss. Barnaul.

5. Saykova, N.V. (2002) Vzaimodeystvie slova i teksta $v$ derivatsionnom aspekte (na materiale vtorichnykh tekstov raznykh tipov) [The interaction of word and text in a derivation aspect (based on secondary texts of various types)]. Philology Cand. Diss. Barnaul.

6. Gorelov, I.N. \& Sedov, K.F. (2001) Osnovy psikholingvistiki [Fundamentals of psycholinguistics]. Moscow: Labirint.

7. Golev, N.D. (2011) Motivational and associative Russian dictionary: theoretical foundationand lexicographic conception. Vestnik Tomskogo gosudarstvennogo universiteta. Filologiya - Tomsk State University Journal of Philology. 3 (15). pp. 17-30. (In Russian).

8. The Russian National Corpus. [Online] Available from: http://www.ruscorpora.ru/searchspoken.html. (Accessed: 02nd February 2016). (In Russian).

9. Evgen'eva, A.P. (ed.) (1985-1988) Slovar' russkogo yazyka: V chetyrekh tomakh [Dictionary of Russian language: in four volumes]. Moscow: Russkiy yazyk.

10. Russian Associative Dictionary. [Online] Available from: http://tesaurus.ru/dict/dict.php. (Accessed: 02nd February 2016). (In Russian). Nauka.

11. Shvedova, N.Yu. (ed.) (1980) Russkaya grammatika [Russian grammar]. Vol. 1. Moscow:

12. Dictionary of Youth Slang. [Online] Available from: http://teenslang.su/content/GN?novar=1. (Accessed: 02nd February 2016). (In Russian). 